\title{
Academic Performance and Technology Acceptance Model (TAM) Through a Flipped Classroom Experience: Training of Future Teachers of Primary Education
}

\author{
Julio Cabero-Almenara \\ Department of Didactics and Educational Organization, Faculty of Education Sciences, University of Seville, Spain \\ ORCID: 0000-0002-1133-6031 \\ Rosalía Romero-Tena \\ Department of Didactics and Educational Organization, Faculty of Education Sciences, University of Seville, Spain \\ ORCID: 0000-0001-9886-8403 \\ Carmen Llorente-Cejudo \\ Department of Didactics and Educational Organization, Faculty of Education Sciences, University of Seville, Spain \\ ORCID: 0000-0002-4281-928X \\ Antonio Palacios-Rodríguez \\ Department of Didactics and Educational Organization, Faculty of Education Sciences, University of Seville, Spain \\ ORCID: 0000-0002-0689-6317
}

\begin{abstract}
In recent years, studies carried out in the educational field have concluded that the Flipped Classroom methodology offers numerous advantages for both teachers and students. In this sense, this approach is worked on at the university to develop skills necessary for the future professional of students, as well as increase their commitment to the subjects. The general objective of this research is to verify if the learning acquired through the Flipped methodology, as well as the perception of it, are useful for university students of the Degree in Primary Education. For this, two types of designs are used: pretest-posttest and validation through structural equations (PLS) of the scale to evaluate the degree of acceptance of the Flipped methodology based on the TAM model. The results show the adequacy of the training proposal based on Flipped methodology for university students. The students perceive the incorporation of the inverted methodology as an adequate strategy, highlighting the ease of use in the classroom, the acceptance of its integration, the transformation of interest in learning and showing a positive attitude towards its use in the future. Together, the level of acceptance as regards the validation of the TAM model is high. Finally, the possibility of replicating the model in similar investigations or through the so-called emerging technologies is evaluated.
\end{abstract}

Keywords: flipped classroom, digital competence, primary education, teacher training, TAM, CFA

\section{INTRODUCTION}

\section{Background}

In most of our universities, traditional learning methodologies centered on the teacher and not on the student continue to be used (Garay et al, 2017; Lai et al., 2018; Pelger \& Nilsson, 2018; Sánchez-Rodríguez). 
Nowadays, Flipped Classroom practices are acquiring a relevant role (Zainuddin et al., 2019). Above all, due to the diversity of possibilities they offer, as the various meta-analyzes on the subject are showing (GalindoDomínguez \& Bezanilla, 2019; Sola et al., 2019).

Generally, Flipped Classroom refers to classroom practice in which content is available to the student through various materials for pre-class study; the activities carried out in class are to deepen the understanding of the content (Brewer \& Movahedazarhouligh, 2018; O'Flaherty \& Phillips, 2015). As Mengual-Andrés et al. (2020, p. 78), "is defined as a pedagogical approach in which the traditional roles of the classroom are inverted so that students start their learning outside the traditional classroom and continue, reinforce and complement it in their regular school hours".

Many of the studies carried out in the studied field conclude that the Flipped Classroom can offer different advantages for both teachers and students. Teachers, for example, allow him to better understand the learning styles and difficulties of students and offer individualized tutoring, as well as taking advantage of class time to understand the contents (Roehl et al., 2013). On the other hand, students are more involved than in traditional classes, provoking positive emotions and attitudes towards learning (Herrera \& Prendes, 2019; Monteagudo et al., 2017; Priporas et al., 2017; Rani \& Muniandy, 2019; Sosa Díaz \& Palau Martín, 2018).

\section{Flipped Classroom: A Student-Centered Method}

In Flipped Classroom, the student's commitment to the teaching-learning process plays a fundamental role (Boekaerts, 2016; Guo, 2018; Lei et al., 2019). Therefore, they must generate an active role in their own learning to acquire the necessary skills for their professional future (Daellenbach, 2018; Fletcher et al., 2017).

Flipped Classroom conforms two types of learning by the student (Bergmann \& Sams, 2012). At first there is individual learning, before class, during which students are exposed to learning content through a variety of media formats, such as video and text (Bergmann \& Sams, 2012; Mohamed \& Lamia, 2018; Sun et al., 2018). A second moment, which focuses on interactive classroom learning, in which students have various types of interactive learning activities, such as questions and answers, explanation of advanced concepts, discussions, problem solving, and collaborative projects (Kim \& Park, 2017; Long et al., 2018). Students in a Flipped Classroom go from being passive learners to active learners (Kim \& Park, 2017; Sun et al., 2018). Rojas (2020), based on Bloom's taxonomy for the digital age, points out how the categories that require lower thinking skills (remembering, understanding and applying) can be developed at home. On the other hand, those of a higher order (analyze, evaluate and create) can be developed in the classroom.

The study carried out by Koh (2019) is based on the ideas of student-centered learning; aims to define the four pedagogical dimensions that should exist in Flipped Classrooms in higher education.

A. Personalization: being student-centered suggests flexibility and choice with learning activities and resources and where teachers use class time to support individual learning needs.

B. Higher order thinking: as a deep and constructive learning so that the class time that was originally used for the transmission of the topic is now focused on activities that promote critical or higher order thinking of the students.

C. Self-direction: supports student autonomy, but in turn requires students to take more responsibility for learning.

D. Collaboration: students have a greater interest in the learning processes of student-centered classrooms and in collaboration through group work.

\section{Teaching-Learning and the Importance of Materials in Flipped Classroom}

If we focus on the didactic act, the teacher is a crucial element in making decisions about how the teachinglearning process will be (Ruiz et al., 2020). Studies focused on higher education teachers and their perceptions on the use of the Flipped Classroom are scarce (Abeysekera \& Dawson, 2015). Most of the recent 
research on the Flipped Classroom focuses on students' experiences, attitudes, and perceptions regarding their learning in the Flipped Classroom (Long et al., 2017; Lopes \& Soares, 2018), but not on the teacher. However, all educational innovations are led by a teacher and it is they who make the decisions to adopt the innovations and implement them.

Another of the fundamental elements is that of the materials designed and selected by the teachers (He et al., 2016; Hung, 2015; O'Flaherty \& Phillips, 2015). Their role is key to promoting optimal learning experiences with the "Flipped Class" (Van Wyk, 2019). As Hung (2015) points out, the preparation and curriculum design of materials before class is essential for students to be motivated and to be able to get involved and achieve more satisfactory results. In this aspect, it is where one of its limitations appears for its incorporation into educational practice (Recio et al., 2020). Generally, there is a lack of teacher training, both for its use and in the domain of teaching digital skills that enable them to design the technological resources to be used (Cabero-Almenara et al., 2020a, 2020b; Guillén-Gámez et al., 20218, 2020; López et al., 2019; Pozo et al., 2020). This is because the materials to be handled must have specific characteristics of time, structure and technologies (Zainuddin \& Attaran, 2016).

Most of the studies that refer to technologies used in the Flipped Classroom have almost always referred to videos. Murillo et al. (2019) point out that the use (and empirical evidence) of said online videos together with mobile devices, social networks and cloud computing applications during the entire teaching-learning process in the Flipped Classroom is one of the greatest benefits provided by this methodology. FindlayThompson and Mombourquette (2014) point to the Flipped Classroom as a teaching model in which students watch lectures outside of class time using different forms of technology, such as prerecorded videos, with the aim of creating a collaborative learning environment.

However, it must be recognized that other technologies are increasingly being incorporated into this teaching strategy, such as augmented reality (Sánchez-García \& Toledo-Morales, 2017), social networks (BlascoSerrano et al., 2018), or gamification (Gómez-Carrasco et al., 2019).

Although some studies have not detected a significant difference in student academic performance between inverted and traditional instructional models (Blair et al., 2016; Davis et al., 2013), it should be noted that the vast majority who have analyzed the significance of this variable has revealed the improvement in performance compared to the traditional face-to-face model (Fuentes et al., 2020; Hinojoso et al., 2020; Long et al., 2016; Luo et al., 2018; Torrecilla, 2018; Torrecilla \& García, 2020). However, many members of the educational community are still hesitant or reluctant to adopt the Flipped Classroom method, as there are numerous factors that can make the change from a traditional environment to a Flipped Classroom method a frustrating process (DeLozier \& Rhodes, 2016; Luo et al., 2018; O’Flaherty \& Phillips, 2015).

Due to the lack of conclusive findings, more empirical evidence is needed on the effect of the Flipped Classroom on academic performance and student satisfaction (Chuang et al., 2018; Luo et al., 2018; O'Flaherty \& Phillips, 2015). The studies carried out by O'Flaherty and Phillips (2015), and DeLozier and Rhodes (2017) presented direct evidence on how academic performance and satisfaction with student training could be positively affected with a Flipped Classroom compared to a traditional method.

Finally, we understand the general satisfaction level of the students as a positive affective state that results from the evaluation of the teacher, the module and the capacity of the teaching and learning method for a better understanding than the traditional approach centered on the student (Awidi \& Paynter, 2019).

\section{Benefits and Difficulties of the Flipped Classroom as a Teaching-Learning Strategy}

The Flipped Classroom has proven to be effective in terms of acquiring knowledge and skills for the professional future of students (Gerstein \& Friedman, 2016; Lopes \& Soares, 2018). Focusing on the relationship between activity-based learning and the Flipped Classroom, Schwarzenberg et al. (2018) observe that the Flipped Classroom increases instructional opportunities among peers when classroom activities promote active learning. All of this helps reduce the effects of prior knowledge on individual students. For this reason, the flexibility it offers when organizing the student's time has been considered a fundamental 
element for the success of the Flipped Classroom, giving them the time they need to carry out the different activities and thus be able to better understand the content of the course (Kim et al., 2014; O'Flaherty \& Phillips, 2015; Wanner \& Palmer, 2015).

According to Tomás et al. (2019) the potential benefits of a Flipped Classroom are tempered by two main concerns: (a) considerable work is required to create and coordinate learning materials and activities, particularly quality Flipped videos, and (b) students may resist to do required work at home and come to class unprepared to participate in planned activities (Herreid \& Schiller, 2013; Milman, 2012). Furthermore, the idea that online videos do not offer enough scaffolding for some students is reinforced, as they cannot ask questions to clarify their ideas in real time (Howitt \& Pegrum, 2015). For this reason, effective teaching for learning requires students to engage in critical thinking to address complex issues (Wals et al., 2014). However, most cases reflect that students have limited customization of learning options and structured collaboration processes are rarely used, apart from the few cases that implement team learning (Koh, 2019). Research carried out has shown that its incorporation into teaching improves relations between students and teachers (García-Gil \& Cremades-Andreu, 2019). The exhaustive analysis of the term "Flipped" by Sánchez-Rodriguez et al. (2017) is remarkable. Their study concludes stating that there are significant benefits with the application of flipped classes, from allowing teachers to identify concepts that their students do not understand, to dedicating time in class to the development of higher order cognitive skills of students. Otro estudio similar es el llevado a cabo por Judy Doru et al. (2020) in a mathematics course for 374 undergraduate Computer Science students. The most significant results indicate that both collaboration and problem solving are enhanced during the Flipped Classroom time.

Finally, it should be noted that, although many studies have investigated the specific activities and practices used in the Flipped Classroom (Chuang et al., 2018; Luo et al., 2018), not enough attention has been paid to the final result of themselves, nor to the satisfaction of the students. In this sense, the Technology Acceptance Model (TAM) becomes an excellent tool to answer this question. In a related study, Bervell and Naufal Umar (2017) evaluate a variant of this model, the Unified Theory of Acceptance and Use of Technology (UTAUT), combined based on linear and non-linear relationships. The results conclude that different societies and cultural contexts produce different behavioral outcomes. Therefore, and as it is intended in this study, models are suitable for evaluating specific learning contexts.

\section{TAM Model for the Analysis of the Acceptance of Emerging Methodologies}

To analyze the degree of acceptance of the Flipped Classroom methodology in this study, one of the most significant models is used to explain the degree of adoption that a person makes of a technology, both general and specific. This model was originally called Technology Acceptance Model (TAM), by Davis (1989). Under its umbrella it is collected that the beliefs, attitudes or predispositions that are had about the technologies will have repercussions on the use that is made of it. To do this, it is determined by two variables: perceived usefulness and perceived ease of use. The TAM model proposes and empirically demonstrates that the Perceived Utility (UP), Perceived Ease of Use (FUP), Perception of Enjoyment (PD), Attitude Toward Use (ACU) and Intent to Use (UI) are the most critical factors in the process of technology adoption and the use of systems (Chen \& Tan, 2004).

Different transformations have been incorporated in different studies (Cabero-Almenara et al., 2016; CaberoAlmenara \& Llorente-Cejudo, 2020; López-Bonilla \& López-Bonilla, 2017). This has been done through the incorporation of new dimensions such as, for example, predictive dimensions (gender, degree of obligation to adopt the technology, experience, age, type of users, etc.). One of these cases is the study carried out by Cabero-Almenara et al. (2018b). In it, two aspects are revealed: first, the validity and consistency of the TAM model, and secondly, its significance for determining the future degree of acceptance of virtual training. This last fact will determine the significance that virtual training can acquire in a training institution.

From the model itself, it is emphasized that it must be built in each and every situation of acceptance of the technologies to be investigated. For this reason, it is exceptionally adapted to the study presented, contextualizing and locating in it the mediating variables that are considered from the researcher's point of view. In this sense, the model has evolved towards other versions, such as TAM 2 (Venkatesh \& Davis, 2000), 
the Unified Theory of Acceptance and Use of Technology (Bervell \& Naufal Umar, 2017; Venkatesh et al. 2003), or the integration model of acceptance of technology and user satisfaction (Venkatesh \& Bala, 2008).

For the TAM application model in Flipped methodologies, the following modifications are made: a) the number of mediating variables is expanded; and b) incorporation of the variables gender, age, technical domain that the person who has the technologies could consider.

\section{METHODOLOGY}

\section{Objectives}

The general objective of the study is to verify whether the learning acquired through the Flipped methodology, as well as the perception of it, are useful for students. Likewise, the study raises the following specific objectives:

- 01 . Check the adequacy of the training proposal based on Flipped methodology for teachers in Primary Education training.

01.1. Check if there are statistically significant differences between the correct answers obtained in the pretest and posttest for the 2 subjects and in a general way.

$\circ$ 01.2. Check if there are statistically significant differences between the errors obtained in the pretest and posttest for the 2 subjects and in general.

- O2. Study the level of acceptance of the Flipped methodology of teachers in Primary Education training:

○ 02.1. Validation of the Flipped Methodology Acceptance Model (TAM).

$\bigcirc$ 02.2. Analysis of the level of acceptance of the Flipped methodology.

\section{Design}

The present study uses two types of designs: pretest-posttest and scale validation with descriptive. The first of these, pretest-posttest, is "one of the most used quasi-experimental designs in educational research" (Cohen et al., 2007, p. 283). In this case, it is a question of checking if there are differences in the student's competence level before and after receiving the training through Flipped Classroom. To do this, a contrast study is carried out on two knowledge questionnaires: "General principles for the use, design and evaluation of media" and "Video in teaching". Regarding the validation of the scale, it is about validating the acceptance scale of the Flipped methodology by adapting the TAM model of Davis (1989). Subsequently, we proceed to provide the most significant data related to the acceptance of the Flipped methodology.

\section{Participants}

All the participants are first-year students of the Primary Education Degree who take the subject of ICT applied to Education. A total of 129 students; 94 women (72.9\%) and 35 men (27.1\%) who voluntarily participated in this study. Despite the significantly lower number of male participants, the sample was considered acceptable, as this gender ratio is typical for ICT-focused Primary Education, Primary and Pedagogy subjects, and a balanced sample would have been too small or unreachable.

\section{Experience Procedure}

The experience carried out in the subject of Technologies applied to Education in the Primary Degree is presented, which is taught in the first year at the Faculty of Education Sciences of the University of Seville. Two subjects of the subject have been worked with inverted methodology (Flipped Classroom) and the rest through their usual programming.

It takes place during the months of February to March 2020, more specifically, from February 12 to March 11. Next, a specific timing for the development of the experience is generated by the teachers involved in 
Table 1. Timing and structure of the development of the experience

\begin{tabular}{lll}
\hline Date & Monday & Rest of the week \\
\hline February 12-23 & Presentation Material T.1 & Individual work \\
March 26-2 & PRETEST & Team work \\
March 5-9 & Platform Material Delivery & Individual work \\
& POSTEST T.1 & \\
March 12-16 & Presentation Material T.2 & \\
\hline
\end{tabular}

the study. Its objective is to minimize the possible external variables that may be generated as much as possible.

For this and, so that all the groups involved follow the same pattern, students are also offered a series of guidelines.

1. Preparation of materials, preparation of the presentation / motivation sheet.

a. The first day it is necessary to explain what the methodology consists of, what structure will be followed, what evaluation it will have, and motivate them in a general way to participate.

2. Outside the classroom: individual work by students and completion of the questionnaire by students.

a. The pre-test is completed.

b. Students, for each of the topics, will be given a document with a video clip (polymedia) and two texts, where they are clearly explained what they have to do with the materials, the importance of that topic, and how you should work them.

c. Students have to generate an individual report on the understanding of the materials, and deliver them before the group work session.

3. In the classroom:

a. Clarification of the teacher of the possible doubts raised.

b. Student work to carry out an activity.

c. Delivery of activities.

d. The post-test is completed.

Finally, to verify the degree of motivation and level of satisfaction that university students arouse by participating in training experiences supported by technological tools with this Flipped Classroom methodology and inquire about technical, curricular and organizational difficulties, the TAM (Davis, 1989). Its application was carried out electronically through the following address: https://cutt.ly/KgOCwOS

\section{Data Analysis Procedure}

Before analyzing the data, it has been found that these are not normally distributed through the study of asymmetry and kurtosis. The "Kolmogorov-Smirnov goodness of fit" test has confirmed this verification, with significance ( $p$-value) equal to .000 for all items (non-normal distribution).

To check if there are statistically significant differences between the pretest and posttest, a contrast design is applied using the Wilcoxon signed rank test for related samples and calculation of the effect size using Cohen's D (01.1, 01.2).

After that, to reach 02.1 , the inverted methodology acceptance model (TAM-Flipped) is validated through an analysis of reliability (Cronbach's Alpha and composite reliability), construct validity (AVE) and modeling of structural equations (PLS). After that, descriptive and central tendency analyzes (O2.2) are carried out. 
Table 2. Rank analysis and rank test with Wilcoxon sign and effect size: posttest-pretest correct answers

\begin{tabular}{|c|c|c|c|c|c|c|}
\hline & Ranks & Average range & Sum of ranges & $Z$ & Sig. & Cohen's D \\
\hline \multirow[t]{2}{*}{ DESIGN TOPIC (T.1) } & Negative ranges & 37.44 & 973.50 & \multirow{2}{*}{-4.884} & \multirow{2}{*}{0.000} & \multirow{2}{*}{0.69} \\
\hline & Positive ranges & 51.98 & 3586.50 & & & \\
\hline \multirow[t]{2}{*}{ VIDEO TOPIC (T.2) } & Negative ranges & 45.60 & 2097.50 & \multirow{2}{*}{-1.170} & \multirow{2}{*}{0.000} & \multirow{2}{*}{0.59} \\
\hline & Positive ranges & 52.95 & 2753.50 & & & \\
\hline \multirow[t]{2}{*}{ GENERAL } & Negative ranges & 48.55 & 1845.00 & \multirow{2}{*}{-4.276} & \multirow{2}{*}{0.000} & \multirow{2}{*}{0.64} \\
\hline & Positive ranges & 63.35 & 4941.00 & & & \\
\hline
\end{tabular}

Table 3. Rank analysis and Wilcoxon signed rank test and effect size: posttest-pretest errors

\begin{tabular}{|c|c|c|c|c|c|c|}
\hline & Ranks & Average range & Sum of ranges & Z & Sig. & Cohen's D \\
\hline \multirow[t]{2}{*}{ DESIGN TOPIC (T.1) } & Negative ranges & 54.54 & 4799.50 & \multirow{2}{*}{-7.571} & \multirow{2}{*}{0.000} & \multirow{2}{*}{1.19} \\
\hline & Positive ranges & 27.04 & 351.50 & & & \\
\hline \multirow[t]{2}{*}{ VIDEO TOPIC (T.2) } & Negative ranges & 55.98 & 3695.00 & \multirow{2}{*}{-3.591} & \multirow{2}{*}{0.000} & \multirow{2}{*}{0.58} \\
\hline & Positive ranges & 43.28 & 1558.00 & & & \\
\hline \multirow[t]{2}{*}{ GENERAL } & Negative ranges & 66.49 & 6317.00 & \multirow{2}{*}{-7.297} & \multirow{2}{*}{0.000} & \multirow{2}{*}{0.89} \\
\hline & Positive ranges & 34.29 & 823.00 & & & \\
\hline
\end{tabular}

The data obtained are analyzed with the statistical package SPSS 23 (descriptive analysis and contrast), and SmartPLS 3 software (modeling structural equations).

\section{RESULTS}

It begins by checking the adequacy of the training proposal based on inverted methodology (O1). First, it is studied whether there are statistically significant differences between the correct answers obtained in the pretest and posttest for the 2 subjects and in general (0.1.1). To do this, we proceed to apply the Wilcoxon signed rank test and calculate the effect size. The results appear in Table 2.

As can be seen, the results show significant values for both tests and in a general way $(\operatorname{sig} .=0.00<0.05)$. Therefore, it can be stated with $99 \%$ confidence that there are statistically significant differences between the level of knowledge demonstrated by the students before and after the development of both topics using the Flipped methodology. In this case, taking into account the analysis of the average range, it is observed that after the development of the topics, the level of knowledge is higher. Specifically, after reviewing the values of Cohen's D (effect size), it can be stated that the differences are large (Cohen, 1988).

Next, it is a question of checking whether there are statistically significant differences between the errors obtained in the pretest and posttest for the 2 subjects and in a general way (02.2). The tests applied are the same as in the previous case. The results are shown in Table $\mathbf{3}$.

Again, the results reveal significant values for both tests and in a general way (sig. $=0.00<0.05$ ). It can be stated with $99 \%$ confidence that there are statistically significant differences between the level of error demonstrated by the students before and after the development of both topics using the Flipped methodology. In this case, taking into account the analysis of the average range, it is observed that after the development of the topics, the level of error decreases. Specifically, after reviewing the values of Cohen's D (1988), it can be stated that the differences are moderately large (video theme) or very large (design theme, and in general).

After having verified the adequacy of the training proposal, we proceed to study the level of acceptance of the inverted methodology (O2). In this case, an adaptation of the technology acceptance model (TAM) suggested by Davis (1988) for the Flipped methodology is created. For this reason, before describing the data, we proceed to validate the adaptation made (02.1).

First, the reliability and construct validity values are shown. In the case of validity, the global result after applying Cronbach's Alpha is 0.928. According to O'Dwyer and Bernauer (2013), this figure implies a high 
Table 4. Values of reliability and validity of construct by dimensions

\begin{tabular}{lccc}
\hline & Cronbach's alpha & Composite reliability & Mean extracted variance (AVE) \\
\hline UP & 0.918 & 0.942 & 0.802 \\
FUP & 0.810 & 0.883 & 0.717 \\
PD & 0.920 & 0.950 & 0.864 \\
ACU & 0.803 & 0.910 & 0.835 \\
IU & 0.856 & 0.993 & 0.874 \\
\hline
\end{tabular}

Table 5. Discriminant validity of the model using the Fornell-Larcker criterion

\begin{tabular}{lccccc}
\hline & ACU & FU & IU & PD & UP \\
\hline ACU & 0.914 & & & & \\
FU & 0.361 & 0.846 & & & \\
IU & 0.783 & 0.286 & 0.935 & 0.929 & 0.896 \\
PD & 0.780 & 0.290 & 0.638 & 0.709 & 0.799 \\
UP & 0.719 & 0.409 & 0.702 & & \\
\hline
\end{tabular}

Table 6. Load model crosses

\begin{tabular}{lllll}
\hline & UP & FUP & PD & ACU \\
\hline UP1 & 0.906 & & & \\
UP2 & 0.857 & & & \\
UP3 & 0.906 & & & \\
UP4 & 0.912 & & & \\
FUP1 & & 0.828 & & \\
FUP2 & 0.793 & & \\
FUP3 & 0.914 & 0.959 & \\
PD1 & & 0.956 & 0.909 \\
PD2 & & 0.871 & 0.919 \\
PD3 & & & \\
ACU1 & & & 0.932 \\
ACU2 & & & & 0.938 \\
IU1 & & & \\
IU2 & & & & \\
\hline
\end{tabular}

level of reliability. Together, we proceed to calculate the indices of reliability, composite reliability and construct validity by dimensions. The results are shown in Table 4.

As can be seen, all the relative reliability results (Alpha and composite reliability) are greater than 0.7 , an adequate minimum value according to Lévy (2006) to indicate acceptable levels. Therefore, it can be stated that the proposed model for the acceptance of the Flipped methodology presents good internal consistency in terms of its block of indicators. Regarding convergent validity, all the indices of mean variance extracted (AVE) are greater than 0.5. This value is taken as a reference by Baggozi and Yi (1988) to indicate that more than $50 \%$ of the construct variances are due to the model indicators. Therefore, it can be stated that the total amount of the variance of the indicators is taken into account by the latent construct.

After that, the discriminant validity of the model is analyzed, which allows us to know if each dimension is different from the others. For this, two techniques are used: the Fornell-Larcker criterion and analysis of the cross loads.

The Fornell-Larcker criterion allows us to check whether the mean extracted variance of a dimension is greater than the variance of the rest of the dimensions. The results are shown in Table 5.

To interpret this table, it must be taken into account that the elements of the diagonal are the square root of the mean extracted variance, and the others the correlations between dimensions. As you can see, all the values that are to the left and below the values of the diagonal are less than them. Therefore, the first criterion of discriminant validity is confirmed. 


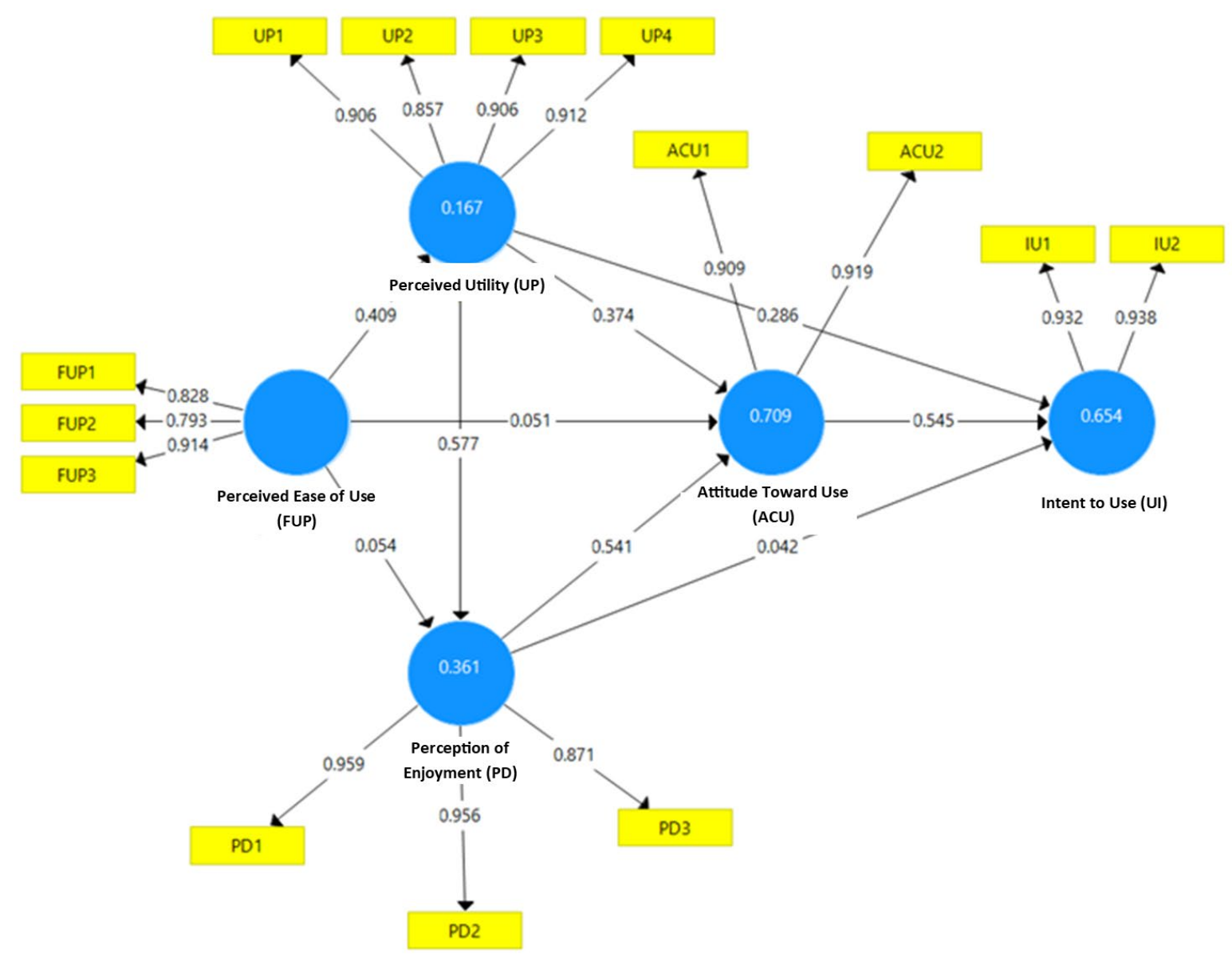

Figure 1. Structural model (TAM-Flipped)

Table 7. Student's t-values and p-values of the path coefficients

\begin{tabular}{lccccc}
\hline Item-Dimension & Original sample & Sample mean & SD & $T$ & P values \\
\hline UP1-UP & 0.299 & 0.298 & 0.14 & 20.629 & 0.000 \\
UP2-UP & 0.229 & 0.227 & 0.023 & 10.022 & 0.000 \\
UP3-UP & 0.296 & 0.297 & 0.017 & 16.972 & 0.000 \\
UP4-UP & 0.291 & 0.292 & 0.015 & 19.429 & 0.000 \\
FUP1-FUP & 0.332 & 0.326 & 0.073 & 4.544 & 0.000 \\
FUP2-FUP & 0.287 & 0.279 & 0.078 & 3.655 & 0.000 \\
FUP3-FUP & 0.544 & 0.556 & 0.089 & 6.103 & 0.000 \\
PD1-PD & 0.368 & 0.009 & 39.413 & 0.000 \\
PD2-PD & 0.368 & 0.373 & 0.011 & 32.547 & 0.000 \\
PD3-PD & 0.372 & 0.334 & 0.015 & 21.688 & 0.000 \\
ACU1-ACU & 0.335 & 0.532 & 0.014 & 37.567 & 0.000 \\
ACU2-ACU & 0.532 & 0.561 & 0.019 & 30.300 & 0.000 \\
IU1-IU & 0.562 & 0.523 & 0.014 & 36.747 & 0.000 \\
IU2-IU & 0.522 & 0.547 & 0.017 & 31.327 & 0.000 \\
\hline
\end{tabular}

The results, higher than 0.7, indicate high levels of correlation (O'Dwyer \& Bernauer, 2013). Therefore, it is ensured that the items measure the construct to which they have been incorporated.

After that, the formulated model is presented by obtaining the standardized regression coefficients (path coefficients), the student's t values and the R2 (R-squared) of the structural diagram (Figure 1).

Regarding the results, the model explains $71 \%$ of the variance in the dimension "Attitude Towards Use", $65 \%$ in the dimension "Intention to Use", $36 \%$ in the dimension "Perception of Enjoyment" and 18\% in the "Perceived Utility" dimension. Table 7 represents the t-values and standardized regression coefficients, as well as the significance of the model after using the bootstrap technique. 
Table 8. Model fit

\begin{tabular}{lcc}
\hline Indicator & Result & Reference \\
\hline SRMR & 0.072 & $<0,08$ \\
Chi-square & 252.995 & $<500$ \\
NFI & 0.792 & $>0.7$ \\
\hline
\end{tabular}

Table 9. Descriptive statistics of the level of acceptance of the inverted methodology (items)

\begin{tabular}{|c|c|c|}
\hline Item & Mean & SD \\
\hline The use of this methodology I think could improve my learning in the classroom (UP1). & 5.04 & 1.12 \\
\hline The use of this methodology during the classes makes it easier for me to understand certain cor & 4.81 & 1.38 \\
\hline I think this methodology is useful when learning (UP3). & 5.16 & 1.11 \\
\hline The use of this methodology favors my learning (UP4). & 4.93 & 1.29 \\
\hline I think the methodology is easy to use & 5.49 & 1.11 \\
\hline Learning to use and c & 5.36 & 1.31 \\
\hline Learning to use and handle it with this methodology has been clear and understandable to me (FUP3). & 5.19 & 1.18 \\
\hline Using it & 4.61 & 1.42 \\
\hline I enjo & 4.66 & 1.37 \\
\hline I believe th & 4.67 & 1.54 \\
\hline The use of this methodology makes learning mor & 5.02 & 1.22 \\
\hline I think its & 5.36 & 1.15 \\
\hline I would like to use this methodology in the future if I have the opportunity (IU1). & 5.19 & 1.35 \\
\hline $\begin{array}{l}\text { I would like to use this methodology to learn both the topics that have been presented to me and with } \\
\text { other topics (IU2). }\end{array}$ & 4.98 & 1.44 \\
\hline
\end{tabular}

Table 10. Descriptive statistics of the level of acceptance of the inverted methodology (dimensions and total)

\begin{tabular}{lcc}
\hline Dimension & Mean & SD \\
\hline Perceived utility (UP) & 4.98 & 1.09 \\
Perceived ease of use (FUP) & 5.34 & 1.01 \\
Perception of enjoyment (PD) & 4.65 & 1.33 \\
Attitude towards use (ACU) & 5.19 & 1.10 \\
Intent to use (UI) & 5.19 & 1.35 \\
Total & 5.07 & 0.94 \\
\hline
\end{tabular}

As can be seen, all the relationships in the model are significant with a confidence level of $99 \%$.

Finally, the goodness of fit of the model is evaluated using the standardized square mean square (SRMR), Chi-square and normalized fit index (NFI). Table $\mathbf{8}$ shows the values obtained, as well as the reference values according to Hu and Bentler (1999).

After validation of the proposed model, an analysis of the level of acceptance of the inverted methodology (O2.2) is carried out. Table 9 shows the means and standard deviations of each of the items that make up the model. For its interpretation, it must be taken into account that the scale used has 7 points $(1=$ Totally disagree / 7 = Totally agree).

All items are above 4.6 points. This implies that, in general, the level of acceptance of the Flipped methodology is moderately high. Specifically, it stands out: ease of use in the classroom (FUP1, FUP2 and FUP3), acceptance of their integration (ACU2), transformation of interest in learning (ACU1) and positive attitude towards its use in the future (IU1).

To specify the analysis, a descriptive analysis by dimensions is carried out. The results can be seen in Table 10.

As can be seen, the students highlight the ease of use (FUP) and show a positive attitude and intention towards its use (ACU and IU). 


\section{DISCUSSION}

The Inverted Classroom methodology is a strategy that is being presented as truly useful and with a great variety of possibilities to facilitate learning by students in different curricular areas and at different educational levels, from kindergarten to university. However, it must be taken into account that considerable efforts are being made to carry out studies and research with the aim of knowing in depth how students learn through it.

The present work has focused on this line. For this, one of the models that is presented as significant in the scientific literature is the TAM, formulated by Davis (1989). This model suggests that the perceived usefulness of a technology and its perceived ease of use will establish values regarding the attitude of use of the same by the subject that will direct it towards a specific intention of use. When it was established to carry out an analysis of the level of acceptance of the inverted methodology through two thematic blocks in the subject of Information and Communication Technologies of the Primary Education Degree (02.2), the results lead to establish one of the first conclusions; The students perceive the incorporation of the inverted methodology as an adequate strategy, highlighting the ease of use in the classroom, the acceptance of its integration, the transformation of interest in learning, and showing a positive attitude towards its use in the future. With all this, it can be affirmed that the training received by the students who have participated in this learning experience has developed satisfactorily.

On the other hand, another of the conclusions that can be derived from this study is that the level of acceptance regarding the validation of the TAM model is high (Teo et al., 2009; Venkatesh \& Bala, 2008). This model presents adequate internal consistency with regard to the block of indicators (Cabero-Almenara et al., 2018b). Therefore, the TAM model used is presented as a good predictor to explain the attitude towards the Flipped Classroom methodology in university education. All this highlights the significance of the model initially formulated by Davis (1989). In this sense, the results obtained are very much in the same line as those achieved by Arteaga and Duarte (2010), or Cabero-Almenara et al. (2018a).

\section{CONCLUSION}

Based on the specific objective of this study, where the need to verify the adequacy of the proposal on the performance tests carried out on students is raised, one of the first conclusions that can be reached with the data obtained is that the methodology of the Flipped learning is adequate in acquiring concepts and knowledge of specific topics. Together, it presents large differences between the scores achieved by the students in the successes of the performance tests before and after having carried out the action.

Likewise, when the verification is carried out based on the data of the academic performance obtained based on the errors, they showed in the same way that the differences in both subjects (Design and Video) in which a Flipped learning methodology was applied, the differences were moderately high. In this sense, it could be concluded that it is proven that the Flipped methodology has a significant effect on the increase in learning by students in a general way, both with regard to the correct answers obtained through the pretest-posttest, as well as the decrease in the number of errors in them.

Finally, it would be interesting to replicate the model in studies and research, but with the application of different methodologies, such as, for example, the Scape-Room, since it also has a high educational potential, or through the incorporation of different technologies, especially, through the so-called emerging technologies or gamification methodologies.

\footnotetext{
Author contributions: All authors were involved in concept, design, collection of data, interpretation, writing, and critically revising the article. All authors approve final version of the article.

Funding: The authors received no financial support for the research and/or authorship of this article.

Declaration of interest: Authors declare no competing interest.

Data availability: Data generated or analysed during this study are available from the authors on request.
} 


\section{REFERENCES}

Abeysekeraa, L., \& Dawsonb, P. (2015). Motivation and cognitive load in the Flipped Classroom: definition, rationale and a call for research. Higher Education Research \& Development, 34(1), 1-14. https://doi.org/10.1080/07294360.2014.934336

Arteaga, R., \& Hueros, A. D. (2010). Motivational factors that influence the acceptance of Moodle using TAM. Computers in Human Behavior, 26(6), 1632-1640.

Awidi, I. T., \& Paynter, M. (2019). The impact of a Flipped Classroom approach on student learning experience. Computers \& Education, 128, 269-283. https://doi.org/10.1016/j.compedu.2018.09.013

Bagozzi, R., \& Yi, Y. (1988). On the evaluation of structural equation models. Journal of the Academy of Marketing Science, 16(1), 74-94. https://doi.org/10.1007/BF02723327

Bergmann, J., \& Sams, A. (2012). Flip your classroom: Reach every student in every class every day. International Society for Technology in Education.

Bervell, B., \& Umar, I. N. (2017). Validation of the UTAUT Model: Re-Considering Non-Linear Relationships of Exogeneous Variables in Higher Education Technology Acceptance Research. Eurasia Journal of Mathematics, Science and Technology Education, 13(10), 6471-6490. https://doi.org/10.12973/ejmste/78076

Bishop, J., \& Verleger, M. A. (2013). The Flipped Classroom: A survey of the research. ASEE.

Blair, E., Maharaj, C., \& Primus, S. (2016). Performance and perception in the Flipped Classroom. Education \& Information Technologies, 21(6), 1465-1482. https://doi.org/10.1007/s10639-015-9393-5

Blasco-Serrano, A., Lorenzo, J., \& Sarsa, J. (2018). Percepción de los estudiantes al 'invertir la clase' mediante el uso de redes sociales y sistemas de respuesta inmediata. RED. Revista de Educación a Distancia, 57(6), 1-19. https://doi.org/10.6018/red/57/6

Boekaerts, M. (2016). Engagement as an inherent aspect of the learning process. Learning and Instruction, 43, 76-83. https://doi.org/10.1016/j.learninstruc.2016.02.001

Brewer, R., \& Movahedazarhouligh, S. (2018). Successful stories and conflicts: A literature review on the effectiveness of Flipped learning in higher education. Journal of Computer Assisted Learning, 34, 409416. https://doi.org/10.1111/jcal.12250

Cabero-Almenara, J., \& Llorente-Cejudo, C. (2020). La adopción de las tecnologías por las personas mayores: aportaciones desde el modelo TAM (Technology Acceptance Model). Publicaciones, 50(1), 141-157. https://doi.org/10.30827/publicaciones.v50i1.8521

Cabero-Almenara, J., Barroso-Osuna, J., \& Llorente-Cejudo, C. (2016). Technology acceptance model. Revista Lasallista de investigación, 13(2), 18-26. https://doi.org/10.22507/rli.v13n2a2

Cabero-Almenara, J., Barroso-Osuna, J., Palacios-Rodríguez, A., \& Llorente-Cejudo, C. (2020a). Marcos de Competencias Digitales para docentes universitarios: su evaluación a través del coeficiente competencia experta [Digital Competences Frameworks for university teachers: their evaluation through the expert competence coefficient]. Revista Electrónica Interuniversitaria De Formación Del Profesorado, 23(2), 1-18. https://doi.org/10.6018/reifop.413601

Cabero-Almenara, J., Gallego-Pérez, O., Puentes-Puente, A., \& Jiménez-Rosa, T. (2018b). La “Aceptación de la Tecnología de la Formación Virtual" y su relación con la capacitación docente en formación virtual [The "Acceptance of Virtual Training Technology" and its relationship with teacher training in virtual training]. EDMETIC, 7(1), 225-241. https://doi.org/10.21071/edmetic.v7i1.10028 
Cabero-Almenara, J., Marín, V., \& Sampedro, B. (2018a). Aceptación del Modelo Tecnológico en la enseñanza superior [Acceptance of the Technological Model in higher education]. Revista de investigación educativa, 36(2), 435-453. https://doi.org/10.15581/004.34.129-153

Cabero-Almenara, J., Romero-Tena, R., \& Palacios-Rodríguez, A. (2020b). Evaluation of Teacher Digital Competence Frameworks Through Expert Judgement: The Use of the Expert Competence Coefficient. Journal of New Approaches in Educational Research, 9(2), 275-293. https://doi.org/10.7821/naer.2020.7.578

Chen, F., Lui, A. M., \& Martinelli, S. M. (2017). A systematic review of the effectiveness of Flipped Classrooms in medical education. Medical Education, 51, 585-597. https://doi.org/10.1111/medu.13272

Chuang, H., Weng, C., \& Chen, C. (2018). Which students benefit most from a Flipped Classroom approach to language learning? British Journal of Educational Technology, 49(1), 56-68. https://doi.org/10.1111/bjet.12530

Cohen, J. (1988). Statistical power analysis for the behavioral sciences. Erlbaum.

Colomo Magaña, E., Gabarda Méndez, V., Cívico Ariza, A., \& Cuevas Monzonís, N. (2020). Percepción de estudiantes sobre el uso del videoblog como recurso digital en educación superior. Píxel-Bit. Revista De Medios Y Educación, 59, 7-25. https://doi.org/10.12795/pixelbit.74358

Daellenbach, K. (2018). On carrot cake and marketing education: A perspective on balancing skills for $\begin{array}{llll}\text { employability. Australasian } & \text { 172-179. }\end{array}$ https://doi.org/10.1016/j.ausmj.2018.04.005

Davis, F. (1989). Perceived usefulness, perceived ease of use, and user acceptance of information technology. MIS Quarterly, 13(3), 319-340. https://doi.org/10.2307/249008

DeLozier, S., \& Rhodes, M. (2016). Flipped Classrooms: A review of key ideas and recommendations for practice. Educational Psychology Review, 29(1), 141-151. https://doi.org/10.1007/s10648-015-9356-9

Dori, Y. J., Kohen, Z., \& Rizowy, B. (2020). Mathematics for Computer Science: A Flipped Classroom with an Optional Project. Eurasia Journal of Mathematics, Science and Technology Education, 16(12), em1915. https://doi.org/10.29333/ejmste/9149

Eid, M. I., \& Al-Jabri, I. M. (2016). Social networking, knowledge sharing, and student learning: The case of $\begin{array}{lllll}\text { university students. Computers \& } \quad \text { Education, } & \text { 99, }\end{array}$ https://doi.org/10.1016/j.compedu.2016.04.007

Findlay-Thompson, S., \& Mombourquette, P. (2014). Evaluation of a Flipped Classroom in an undergraduate business course. Business Education \& Accreditation, 6(1), 63-71.

Fletcher, A. J., Sharif, A. W., \& Haw, M. D. (2017). Using the perceptions of chemical engineering students and graduates to develop employability skills. Education for Chemical Engineers, 9, 11-25. https://doi.org/10.1016/j.ece.2016.07.001

Galindo-Domínguez, H., \& Bezanilla, M. (2019). Una revisión sistemática de la metodología Flipped Classroom a nivel universitario en España. Innoeduca. International Journal of Technology and Educational Innovation, 5(1), 81-90. https://doi.org/10.24310/innoeduca.2019.v5i1.4470

Garay, U., Tejada, E., \& Castaño, C. (2017). Percepciones del alumnado hacia el aprendizaje mediante objetos educativos enriquecidos con realidad aumentada. EDMETIC, 6(1), 145-164. https://doi.org/10.21071/edmetic.v6i1.5812

García-Gil, D. y Cremades-Andreu, R. (2019). Flipped Classroom en educación superior Un estudio a través de relatos de alumnos. Revista Mexicana de Investigación Educativa, 24(80), 101-123. 
Gerstein, M., \& Friedman, H. H. (2016). Rethinking higher education: Focusing on skills and competencies. Psychosociological Issues in Human Resource Management, 4(2), 104-121.

Gómez-Carrasco, C., Monteagudo-Fernández, J. y Moreno-Vera, J. (2019). Effects of a Gamification and Flipped-Classroom Program for Teachers in Training on Motivation and Learning Perception. Education Sciences, 9, 299. https://doi.org/10.3390/educsci9040299

Guillén-Gámez, F. D., Álvarez-García, F. J., \& Rodríguez, I. M. (2018). Digital tablets in the music classroom: A study about the academic performance of students in the BYOD context. Journal of Music, Technology \& Education, 11(2), 171-182. https://doi.org/10.1386/jmte.11.2.171_1

Guillén-Gámez, F. D., Mayorga-Fernández, M. J., Bravo-Agapito, J., \& Escribano-Ortiz, D. (2020). Analysis of teachers' pedagogical digital competence: Identification of factors predicting their acquisition. Technology, Knowledge and Learning, 4, 1-18. https://doi.org/10.1007/s10758-019-09432-7

Guo, J. (2018). Building bridges to student learning: Perceptions of the learning environment, engagement, and learning outcomes among Chinese undergraduates. KLM.

Hasan, A. (2017). The Effect of Directed Reading Thinking Activity (DRTA) Method on Students' Reading Comprehension for State Islamic Senior High School. Journal of English and Arabic Language Teaching, $8(2), 140-148$.

He, W., Holton, A., Farkas, G., \& Warschauer, M. (2016). The effects of Flipped instruction on out-of-class study time, exam performance, and student perceptions. Learning and Instruction, 45, 61-71. https://doi.org/10.1016/j.learninstruc.2016.07.001

Herrera, G., \& Prendes, P. (2019). Implementación y análisis del método de aula invertida: un estudio de caso en Bachillerato. Innoeduca. International Journal of Technology and Educational Innovation, 5(1), 2433. https://doi.org/10.24310/innoeduca.2019.v5i1.3091

Hinojoso, F, López, J., Fuentes, A., Trujillo J. \& Pozo, S. (2020). Academic Effects of the Use of Flipped Learning in Physical Education. International Journal of Environmental Research and Public Health, 17, 276. https://doi.org/10.3390/ijerph17010276

Howitt, C., \& Pegrum, M. (2015). Implementing a Flipped Classroom approach in postgraduate education: An unexpected journey into pedagogical redesign. Australasian Journal of Educational Technology, 31(4), 458-469. https://doi.org/10.14742/ajet.2439

Howland, J., Jonassen, D., \& Marra, R. (2013). Meaningful learning with technology. New Pearson Higher Education.

Hu, L. \& Bentler, P. (1999). Cutoff criteria for fi t indexes in covariance structure analysis: Conventional criteria versus new alternatives. Structural Equation Modeling: A Multidisciplinary Journal, 6(1), 1-55.

Kim, J., \& Park, H. (2017). Exploring Flipped Classroom effects on second language learners' cognitive processing. Foreign Language Annals, 50(2), 260-284. https://doi.org/10.1111/flan.12260

Kim, M., Kim, S., Khera, O., \& Getman, J. (2014). The experience of three Flipped Classrooms in an urban university: An exploration of design principles. The Internet and Higher Education, 22, 37-50.

Koh, J. (2019). Four pedagogical dimensions for understanding Flipped Classroom practices in higher education: A systematic review. Educational Sciences: Theory and Practice, 19(4), 14 - 33. https://doi.org/10.12738/estp.2019.4.002

Lai, H. M., Hsiao, Y. L., \& Hsieh, P. J. (2018). The role of motivation, ability, and opportunity in university teachers' continuance use intention for Flipped teaching. Computers \& Education, 124, 37-50.

Lei, M., Clemente, I., \& Hu, Y. (2019). Student in the shell: The robotic body and student engagement. Computers \& Education, 130, 59-80. https://doi.org/10.1016/j.compedu.2018.11.008 
Lévy, J. (2006). Modelización con estructuras de covarianzas en ciencias sociales: temas esenciales, avanzados y aportaciones especiales. Netbiblo

Long, T., Cummins, J., \& Waugh, M. (2016). Use of the Flipped Classroom instructional model in higher education: instructors' perspectives. Journal of Computer in Higher Education, 29(2), 179-200. https://doi.org/10.1007/s12528-016-9119-8

Long, T., Logan, J., \& Waugh, M. (2016). Students' perceptions of the value of using videos as a pre-class learning experience in the Flipped Classroom. TechTrends, 60(3), 245-252.

Long, T.; Cummins, J. \& Waugh, M. (2019). Investigating the factors that influence higher education instructors' decisions to adopt a Flipped Classroom instructional model. British Journal of Educational Technology, 50(4), 2028-2039. https://doi.org/10.1111/bjet.12703

Lopes, A. P., \& Soares, F. (2018). Perception and performance in a Flipped Financial Mathematics classroom. International Journal of Management in Education, 16(1), 105-113. https://doi.org/10.1016/j.ijme.2018.01.001

López, J., Pozo, S. \& Del Pino, M. (2019). Projection of the Flipped Learning Methodology in the Teaching Staff of Cross-Border Contexts. Journal of New Approaches in Educational Research, 8(2), 184-200. https://doi.org/10.7821/naer.2019.7.431

López-Bonilla, L., \& López-Bonilla, J. (2017). Explaining the discrepancy in the mediating role of attitude in the TAM. British Journal of Educational Technology, 48(4), 940-949. https://doi.org/10.1111/bjet.12465

Luo, A., Yang, T., Xue, J., \& Zuo, X. (2018). Impact of student agency on learning performance and learning experience in a Flipped Classroom. British Journal of Educational Technology, 6, 25-40. https://doi.org/10.1111/bjet.12604

Mengual-Andrés, S., López, J., Fuentes, A., \& Pozo, S. (2020). Modelo estructural de factores extrínsecos influyentes en el Flipped learning. Educación XX1, 23(1), 75-101. https://doi.org/10.5944/educXX1.23840

Mohamed, H., \& Lamia, M. (2018). Implementing Flipped Classroom that used an intelligent tutoring system into learning process. Computer \& Education, 124, 62-76. https://doi.org/10.1016/j.compedu.2018.05.011

Munoz-Merino, P., Ruiperez-Valiente, J., Kloos, C., Auger, M., Briz, S., De Castro, V., \& Santalla, S. (2017). Flipping the classroom to improve learning with MOOCs technology. Computer Applications in Engineering Education, 25, 15-25. https://doi.org/10.1002/cae.21774

Murillo-Zamorano, L., López Sánchez, J., \& Godoy-Caballero, A. (2019). How the Flipped Classroom affects knowledge, skills, and engagement in higher education: Effects on students' satisfaction. Computers \& Education, 26, 141-160. https://doi.org/10.1016/j.compedu.2019.103608

O'Dwyer, L., \& Bernauer, J. (2013). Quantitative research for the qualitative researcher. SAGE publications.

O'Flaherty, J., \& Phillips, C. (2015). The use of Flipped Classrooms in higher education: A scoping review. The Internet and Higher Education, 25, 85-95. https://doi.org/10.1016/j.iheduc.2015.02.002

Pelger, S., \& Nilsson, P. (2018). Observed learning outcomes of integrated communication training in science education: Skills and subject matter understanding. Studies in Educational Evaluation, 59, 195-208. https://doi.org/10.1080/21548455.2017.1417653 
Pozo, S., López, J., Moreno, A., \& Hinojoso-Lucena, F. (2020). Flipped learning y competencia digital: Una conexión docente necesaria para su desarrollo en la educación actual [Flipped learning and digital competence: A necessary teaching connection for its development in today's education]. Revista Electrónica Interuniversitaria de Formación del Profesorado, 23(2), 127-141. https://doi.org/10.6018/reifop.422971

Priporas, C., Stylos, N., \& Fotiadis, A. K. (2017). Generation Z consumers' expectations of interactions in smart retaing: A future agenda. Computers in Human Behavior, 77, 374-381. https://doi.org/10.1016/j.chb.2017.01.058

Rani, S., \& Muniandy, B. (2019). The Effect of Flipped Classroom on Students' Engagement. Tech Know Learn, 24, 355-372. https://doi.org/10.1007/s10758-017-9343-y

Recio, F., Silva, J., \& Abricot, N. (2020). Análisis de la Competencia Digital en la Formación Inicial de estudiantes universitarios: Un estudio de meta-análisis en la Web of Science [Analysis of Digital Competence in the Initial Training of university students: A meta-analysis study in the Web of Science]. Píxel-Bit. Revista De Medios Y Educación, 59, 125-146. https://doi.org/10.12795/pixelbit.77759

Rojas, J. (2020). Modelo Flipped learning aplicado a la asignatura de sistemas operativos y de la carrera de informática de la UCE: estudio de caso para medir el nivel de motivación y atisfacción tecnológica en el uso de la plataforma Moodle [Flipped learning model applied to the subject of operating systems and the computer science career of the UCE: case study to measure the level of motivation and technological atisfaction in the use of the Moodle platform]. Universidad de Alicate.

Ruiz, A., Medina, M., Pérez, E., \& Medina, A. (2020). University teachers' training: the Digital Competence. Píxel-Bit. Revista De Medios Y Educación, 58, 181-215. https://doi.org/10.12795/pixelbit.74676

Sánchez-García, J. M., \& Toledo-Morales, P. (2017). Tecnologías convergentes para la enseñanza: Realidad Aumentada, BYOD, Flipped Classroom [Converging Technologies for Teaching: Augmented Reality, BYOD, Flipped Classroom]. Revista de Educación a Distancia (RED), 17(55).

Sánchez-Rodríguez, J., Ruiz-Palmero, J., \& Sánchez-Vega, E. (2017). Flipped classroom. Claves para su puesta en práctica [Flipped classroom. Keys for its implementation]. EDMETIC, 6(2), 336-358. https://doi.org/10.21071/edmetic.v6i2.5832

Schwarzenberg, P., Navon, J., Nussbaum, M., Pérez-Sanagustín, M., \& Caballero, D. (2018). Learning experience assessment of Flipped courses. Journal of Computing in Higher Education, 30(2), 237-258. https://doi.org/10.1007/s12528-017-9159-8

Sola, T., Aznar, I., Romero, J., \& Rodríguez-García, A. (2019). Eficacia del Método Flipped Classroom en la Universidad: Meta-Análisis de la Producción Científica de Impacto [Efficacy of the Flipped Classroom Method at the University: Meta-Analysis of Scientific Impact Production]. REICE. Revista Iberoamericana sobre Calidad, Eficacia y Cambio en Educación, 17(1), 25-38. https://doi.org/10.15366/reice2019.17.1.002

Sosa Díaz, M. J., \& Palau Martín, R. F. (2018). Flipped Classroom para adquirir la competencia digital docente: una experiencia didáctica en la Educación Superior [Flipped Classroom to acquire teaching digital competence: a didactic experience in Higher Education]. Píxel-Bit. Revista De Medios y Educación, 52, 37-54. https://doi.org/10.12795/pixelbit.2018.i52.03

Sun, Z., Xie, K., \& Anderman, L. (2018). The role of self-regulated learning in students' success in Flipped undergraduate math courses. The Internet and Higher Education, 36, 41-53. https://doi.org/10.1016/j.iheduc.2017.09.003 
Teo, T., Beng, Ch., Sing, C., Cha, S., \& Luan, S. (2009). Assessing the intention to use technology among preservice teachers in Singapore and Malaysia: A multigroup invariance analysis of the Technology Acceptance Model (TAM). Computers \& Education, 53, 1000-1029. https://doi.org/10.1016/j.compedu.2009.05.017

Tomas, L., Evans, N., Doyle, T., \& Skamp, K (2019). Are first year students ready for a Flipped Classroom? A case for a Flipped learning continuum. International Journal of Educational Technology in Higher Education, 16(5). https://doi.org/10.1186/s41239-019-0135-4

Torrecilla, S. (2018). Flipped Classroom: Un modelo pedagógico eficaz en el aprendizaje de Science [Flipped Classroom: An effective pedagogical model in learning Science]. Revista Iberoamericana de Educación, 76(1), 9-22. https://doi.org/10.35362/rie7612969

Torrecilla, S., \& García, M. (2020). Flipped Classroom: estrategias de aprendizaje y rendimiento en ciencias [Flipped Classroom: Science Learning and Achievement Strategies]. Edutec. Revista Electrónica De Tecnología Educativa, (72), 112-124. https://doi.org/10.21556/edutec.2020.72.1525

Van Wyk, M. (2019). Flipping the Economics Class in a Teacher Education Course. Technology. Knowledge and Learning, 24, 373-399. https://doi.org/10.1007/s10758-018-9377-9

Venkatesh, V., \& Bala, H. (2008). Technology acceptance model 3 and a research agenda on interventions. Decision Sciences, 39(2), 273-312.

Venkatesh, V., \& Davis, A. (2000). Theoretical Extension of the Technology Acceptance Model: Four Longitudinal Field Studies. Management Science, 46(2), 186-204.

Wals, A., Brody, M., Dillon, J., \& Stevenson, R. (2014). Convergence between science and environmental education. Science, 344(6184), 583-584. https://doi.org/10.1126/science.1250515

Wanner, T., \& Palmer, E. (2015). Personalising learning: Exploring student and teacher perceptions about flexible learning and assessment in a Flipped university course. Computers \& Education, 88, 354-369. https://doi.org/10.1016/j.compedu.2015.07.008

Wu, W., Jun, S., \& Yang, J. (2017). Creating an online learning community in a Flipped Classroom to enhance EFL learners' oral proficiency. Journal of Educational Technology \& Society, 20, 142-157.

Zainuddin, Z. (2018). Students' learning performance and perceived motivation in gamified Flipped-class instruction. Computers \& Education, 126, 75-88. https://doi.org/10.1016/j.compedu.2018.07.003

Zainuddin, Z., \& Attaran, M. (2016). Malaysian students' perceptions of Flipped Classroom: a case study. Innovations in Education and Teaching International, 53(6), 660-670. https://doi.org/10.1080/14703297.2015.1102079

Zainuddin, Z., Habiburrahim, H., Muluk, S., \& Keumala, C. (2019). How do students become self-directed learners in the EFL Flipped-class pedagogy? A study in higher education. Indonesian Journal of Applied Linguistics, 8(3), 678-690. https://doi.org/10.17509/ijal.v8i3.15270

Correspondence: Antonio Palacios-Rodríguez, Department of Didactics and Educational Organization, Faculty of Education Sciences, University of Seville. E-mail: aprodriguez@us.es 